\title{
Filozoficzny anarchizm, czyli jak być dobrym obywatelem nieposłusznym państwu i prawu*
}

Każdy kto dysponuje chociażby tylko podstawową wiedzą z zakresu myśli politycznej, zgodzi się, iż najbardziej niekwestionowanym, a tym samym najtwardszym wspólnym mianownikiem wszelkich doktryn anarchistycznych jest odrzucenie państwa. Rzeczywiście, w doktrynach tych samo istnienie państwa - jako instytucji, która przypisuje sobie najwyższy suwerenny autorytet, która w jego obronie stosuje przymus, która użycie tego przymusu monopolizuje i która w ten sposób kreuje autorskie sztuczne podziały społeczne ${ }^{1}$ - stanowi barierę dla naturalnego, spontanicznego, a więc wolnego, nieskrępowanego rozwoju tak jednostki, jak i społeczeństwa. To wspólne dla doktryn anarchistycznych założenie pozwala przyjąć, iż w jakiejkolwiek z nich nie może być miejsca zarówno na zagadnienie autorytetu państwa, jak politycznego zobowiązania jego obywateli ${ }^{2}$. Innymi słowy, zagadnienie moralnej więzi obywa-

\footnotetext{
* Tekst jest referatem drukowanym równolegle w materiałach konferencji historyków doktryn politycznych i prawnych, odbytej w 2012 r. w Szklarskiej Porębie. Redakcja dziękuje organizatorom konferencji za udostępnienie tekstu referatu.

${ }^{1}$ Miller wskazuje na anarchistyczne rozumienie państwa jako unikalnej instytucji, wyróżnionej przez takie właśnie cztery charakterystyczne cechy: „Po pierwsze, państwo jest ciałem suwerennym w takim sensie, iż zgłasza roszczenie do wszelkiego autorytetu definiowania uprawnień swoich poddanych - nie zezwala na przykład na cieszenie się prawami wynikającymi ze zwyczaju jeśli tylko tych praw samo nie ustanowiło lub nie utrzymało w mocy. Po drugie, państwo jest ciałem opartym na przymusie w tym sensie, iż każdy kto przychodzi na świat w danym społeczeństwie, jest zmuszony do uznania zobowiązań wobec państwa, które sprawuje władzę nad tym społeczeństwem - nikt nie może odrzucić tych zobowiązań jeśli nie porzuci tego społeczeństwa. Po trzecie, państwo jest ciałem monopolistycznym. Sprawuje ono monopol na użycie siły obszarze swojego terytorium i nie pozwala żadnemu konkurentowi na istnienie obok siebie. Po czwarte, państwo jest szczególnym ciałem w tym sensie, że role i funkcje, które się nań składają są oddzielone od ról i funkcji społecznych w ogóle, a więc tym, że ludzie, którzy tworzą państwo najczęściej tworzą odrębną klasę - polityków, biurokratów, funkcjonariuszy sił zbrojnych i policyjnych”. D. Miller, Anarchism, London 1984, s. 5.

${ }^{2}$ Zagadnienie politycznego zobowiązania, a więc powodów, dla których obywatel jest winien posłuszeństwo państwu i prawu stanowi przedmiot intensywnych, wspólnych dociekań współczesnej anglosaskiej filozofii politycznej i filozofii prawa. Poręczne wprowadzenie do poszczególnych
} 
teli z państwem, z której wynikałoby uprawnienie państwa do wydawania rozkazów swoim obywatelom, szczególnie $\mathrm{w}$ formie postanowień prawa $\mathrm{z}$ jednej strony, a z drugiej ich zobowiązanie do posłuszeństwa państwu, szczególnie poprzez przestrzeganie stanowionego przezeń prawa, jest w jakiejkolwiek doktrynie anarchistycznej bezprzedmiotowe. Tak jednak nie jest. We współczesnej anarchistycznej filozofii politycznej wyrafinowana refleksja nad problematyką politycznego zobowiązania zajmuje poczesne miejsce.

By tego dowieść, postaram się, po pierwsze, przedstawić założenia współczesnego tak zwanego anarchizmu filozoficznego. W dalszej kolejności wskażę na dwie jego postacie. A zatem, po drugie, zarysuję argumentację apriorycznego filozoficznego anarchizmu oraz, po trzecie, aposteriorycznego filozoficznego anarchizmu. Po czwarte, zrekonstruuję zarówno dominującą w literaturze przedmiotu krytykę filozoficznego anarchizmu, jak też jego przed tą krytyką obronę. W konkluzjach będę próbował wskazać, w jaki sposób refleksja filozoficznego anarchizmu może przyczynić się do rozwoju liberalnej myśli politycznej.

I. Istota filozoficznego anarchizmu. Każda anarchistyczna doktryna zakłada, iż państwo jest instytucją pozbawioną autorytetu, a więc uprawnienia do sprawowania władzy nad jego obywatelami. A zatem przyjmuje się, że skoro państwo nie cieszy się legitymacją do rządzenia swymi obywatelami, to także oni nie są zobowiązani do posłuszeństwa.

Dla wielu anarchistów tak teoretyków, jak na przykład Michaił Bakunin ${ }^{3}$, jak i praktyków, jak chociażby Andreas Baader i Ulrike Meinhof ${ }^{4}$ to założenie

ideowo zdeterminowanych ujęć tego zagadnienia daje Dudley Knowles, Political Obligation: A Critical Introduction, London 2010. Najbardziej klasyczne liberalne interpretacje politycznego zobowiązania stanowią: J. Plamenatz, Consent, Freedom and Political Obligation, Oxford 1936; J. Tussman, Obligation and the Body Politic, New York 1960 oraz H. Beran, The Consent Theory of Political Obligation, London 1987. Najbardziej prominentne propozycje rewizji tego klasycznego ujęcia zawierają: C. Pateman, The Problem of Political Obligation: A Critique of Liberal Theory, Cambridge 1979; A.J. Simmons, Moral Principles and Political Obligations, Princeton 1979; G. Klosko, The Principle of Fairness and Political Obligation. New Edition, Lanham 2004; M. Gilbert, A Theory of Political Obligation, Oxford 2006. W polskiej literaturze przedmiotu krytyczną rekonstrukcję klasycznej liberalnej interpretacji politycznego zobowiązania oferuje Z. Rau, Pięć tez trwardogłowego liberała, czyli jak z własnej zgody wyprowadzić postuszeństwo państwu i prawu, w: Filozofia polityczna po roku 1989. Teoria, historia, praktyka, pod. red. Justyny Miklaszewskiej i Jakuba Szczepańskiego, Kraków 2011, s. 155-175.

${ }^{3}$ „Albo burżuazyjno-cywilizowany świat poskromi i ujarzmi żywiołowy bunt ludu i siłą bagnetów, knuta lub pałki, siłą pobłogosławioną oczywiście przez tego lub innego boga i usprawiedliwioną w sposób racjonalny, naukowy zmusi masy robotnicze, by pracowały jak dawniej - co bezpośrednio prowadziłoby do całkowitego odbudowania państwa w jego najbardziej autentycznej postaci, jedynej możliwej w dzisiejszych czasach, a więc w postaci dyktatury wojskowej lub cesarstwa; albo też masy robotnicze zrzucą ostatecznie ze swych bark znienawidzone wielowiekowe jarzmo, zburzą fundamenty burżuazyjnego wyzysku i zbudowaną na nim burżuazyjna cywilizację czyli, innymi słowy, zwycięży Rewolucja Socjalna, druzgocząc wszystko, co się zwie państwem”. Mihail Aleksandrowicz Bakunin, Bóg i państwo, Oficyna Wydawnicza „Trójki” 2012, s. 101.

${ }^{4}$ Patrz na przykład Stefan Aust, The Baader-Meinhof Group: The Inside Story of A Phenomenon, translated from the German by Anthea Bell, London 1987 oraz Baader-Meinhof Returns: 
zawiera w sobie projekt polityczny, który sprowadza się do likwidacji państwa (często poprzez celowe działanie przy użyciu siły). Obecność takiego projektu politycznego pozwala określić ich anarchizm mianem anarchizmu politycznego. Jego kwintesencją jest przekonanie, iż samo istnienie państwa jest faktem, którego ciężar moralny jest tak wielki, że kreuje on absolutny moralny imperatyw jego zniszczenia. Innymi słowy, państwo, które będąc $\mathrm{z}$ istoty swej pozbawione wszelkiej legitymacji, postępuje tak jakby ją posiadało i oczekuje od swych obywateli posłuszeństwa, powoduje, że po ich stronie powstaje obowiązek jego obalenia. Jest to fundament moralnego uzasadnienia dla politycznego projektu, który ma zostać zrealizowany w anarchistycznej praktyce społecznej.

Anarchizm, który nosi nazwę filozoficznego, nie promuje i nie uzasadnia żadnego projektu politycznego. Jest tak dlatego, iż nie kwestionując ani braku jakiejkolwiek legitymacji po stronie państwa, ani braku jakiegokolwiek obowiązku posłuszeństwa po stronie jego obywateli anarchizm ten nie przypisuje samemu istnieniu państwa unikatowego moralnego ciężaru, nieporównywalnego z żadnymi innymi. Tym samym nie przypisuje obowiązkowi obalenia państwa żadnego szczególnego moralnego charakteru, który pozwoliłby określić ten obowiązek jako absolutny czy ostateczny. Filozoficzny anarchizm nie wyklucza takiego obowiązku, ale zawsze jest gotów porównywać go z innymi moralnymi obowiązkami, jakie mają obywatele, chociażby wobec innych osób, idei czy instytucji. A zatem, jak długo sądy moralne tychże obywateli nie przyznają absolutnego pierwszeństwa moralnemu obowiązkowi obalenia państwa nad ich pozostałymi moralnymi obowiązkami i jak ten moralny obowiązek obalenia państwa nie zwycięży w konfrontacji z tym co w literaturze anglosaskiej nazywa się obowiązkami czy zobowiązaniami pochodzącymi z rozwagi (prudential duties, prudential obligations), a więc tymi najbardziej pragmatyczni, które wyprowadza się z kalkulacji szans czy kosztów próby obalenia państwa, tak długo obywatele szukają modus vivendi z państwem. Refleksja, która próbuje konceptualizować ich kondycję, stanowi właśnie kwintesencję filozoficznego anarchizmu.

Dla filozoficznych anarchistów istnienie państwa sprowadza się do obecności w ich otoczeniu jeszcze jednego potężnego i wpływowego podmiotu (sąsiada, kolegi, wspólnika) ${ }^{5}$, którego postępowanie, szczególnie domaganie się wykonywania jego poleceń, można ignorować tam tylko gdzie się tylko da, czyli tam gdzie zarówno moralne, jak i rozważne działanie na to pozwala. Nie znaczy to zatem, by filozoficzni anarchiści swoim działaniem różnili się zasadniczo od innych obywateli, którzy postępują zgodnie z oczekiwaniami

History and Culture Memory of German Left Wing Terrorism, G.J. Berendse and Ingo Cornilus, eds., Amsterdam 2008.

${ }^{5}$ Por. A.J. Simmons, Philosophical Anarchism, w: For and Against the State. New Philosophical Readings, J.T. Sanders, J. Neverson, eds., Lanham 1996, s. 22. 
państwa, a więc przede wszystkim zgodnie z postanowieniami prawa. Jest tak dlatego, że uznają oni, iż istnieje wiele moralnych powodów do takiego właśnie postępowania. Powody te nie wynikają bynajmniej z tego, że wymagają tego od nich postanowienia stanowionego przez organy państwa prawa, lecz dlatego, iż uznają oni moralną zasadność powstrzymania się, na przykład od zabójstw, kradzieży, oszustw, wyłudzeń itd. Co więcej, obywatele ci mają także powody, aby nie dopuszczać się czynów, które same w sobie nie stanowią moralnego zła, ale są zakazane przez prawo. Czyny takie nie pozwalają postępować w sposób spójny i przewidywalny w sytuacjach, kiedy postępowanie niespójne i nieprzewidywalne byłoby niepożądane. Najlepszym przykładem jest tu przestrzeganie przez obywateli zasad ruchu drogowego, nakazujących poruszanie się po prawej lub lewej stronie. Niezależnie od tego nakazu prawa rozwaga wskazuje na zasadność zakazu poruszania się raz po jednej, raz po drugiej stronie, gdyż wystawiałoby na szwank (przypominający hazard) życie i zdrowie uczestników tego ruchu. Niezwykle ważnym argumentem filozoficznych anarchistów jest tutaj to, iż powstrzymywanie się od takich czynów ze strony obywateli wynika $\mathrm{z}$ ich własnych sądów (tak moralnych, jak i tych wynikających z rozwagi) oraz ich własnej woli. Innymi słowy, to nie sąd o rzeczach państwa i jego organów oraz nie wola państwa czy wola państwowego prawodawcy powoduje powstrzymanie się obywateli od takich czynów lecz ich własne przekonania i potrzeby określonego postępowania ${ }^{6}$.

Takie stanowisko otwiera (lub zamyka) drogę do faktycznej współpracy obywateli z państwem. Filozoficzny anarchizm przyjmuje tutaj, iż możliwy zakres takiej współpracy zależy nie tyle od obywateli, ile od państwa. Jego argument sprowadza się do tego, że państwa choć wszystkie cierpią na brak autorytetu, a pozbawione legitymacji nie są uprawnione do posłuszeństwa swych obywateli, to jednak nieco różnią się swoim postępowaniem. Filozoficzny anarchizm przyznaje, że współczesne państwa demokratyczne, bo na takich faktycznie koncentruje się jego refleksja, mogą szczycić się imponującymi osiągnięciami, które jednak mają niebagatelnie wysoką cenę. Jak to ujmuje jego najbardziej wyrazisty i prominentny przedstawiciel:

Jestem gotów przyznać, (co najmniej arguendo), że wszystko co powiada się o osiągnięciach współczesnych państw i współczesnych systemów prawnych, o ich znaczeniu (a nawet ich konieczności) dla skutecznego zapewniania (stosunkowo) bezpiecznego otoczenia pod rządami prawa; o ich znaczeniu (a nawet

${ }^{6}$ Jak to ujmuje Wolff, obywatel wtedy ,nie jest poddanym woli nikogo innego. Może czynić to co inny [państwo czy prawo - przypis mój Z. R.] mu nakazuje, ale nie dlatego, że inny mu tak nakazuje". R.P. Wolff, In Defense of Anarchy, Berkeley 1998, s. 14. Por. krytyczną prezentację tego ujęcia w: C. Gans, Philosophical Anarchism and Political Disobedience, Cambridge 1992, s. 1418. 
konieczności) dla rozwiązywania (...) problemów, które bez państwa i prawa dałyby się we znaki nawet stosunkowo stabilnym stosunkom społecznym; w konsekwencji o ich znaczeniu (a nawet ich konieczności) dla zapewnienia szerokiego zakresu dóbr publicznych. Przyznając to wszystko, trzeba też jednak stwierdzić, iż ma to miejsce za określoną cenę. Mam tu na myśli nie tylko niezbędną cenę jaką trzeba płacić za (...) niepodległość i samostanowienie. Państwa i systemy prawne mogą dokonywać wszystkich tych dobrych rzeczy tylko koncentrując ogromna władzę, a skoncentrowana ogromna władza jest rzeczą ogromnie niebezpieczną. Moralna postawa współczesnych państw jest daleka od wzorowej. Umożliwiają one (i to przygnębiająco często) zabójstwa, terror, prześladowania, niesprawiedliwość i manipulację na skalę, która inaczej byłaby niewyobrażalna. Nawet przyzwoite i zasadniczo sprawiedliwe państwa (...), mimo swoich zalet, dopuszczały się w przeszłości wielkiego zła i nadal z rozmachem kontynuują utrwalanie społecznych (etnicznych, religijnych czy rasowych) hierarchii, instytucjonalizowanie postaw protekcjonalnych i moralizatorskich, (...) wymuszanie kontroli tak osób, jak i narodów poza swoim własnym terytorium?

Filozoficzny anarchizm nie tylko nie dzieli państw na te posiadające autorytet lub nieposiadające go, lecz także na te dobre, sprawiedliwe, pomocne oraz te, które takich pozytywnych cech nie posiadają. W rzeczy samej, to ostatnie rozróżnienie, jakkolwiek teoretycznie zasadne w praktyce politycznej współczesnych państw demokratycznych, występuje niezwykle rzadko. W ujęciu filozoficznego anarchizmu państwa faktycznie różnią się one tylko pewnym stopniem realizacji oczekiwań obywateli co do tego, na ile sprawnie zapewniają korzyści wiązane ze swoim funkcjonowaniem. To na tej podstawie można wskazać, na ile te państwa zasługują na wsparcie czy współpracę swoich obywateli. Przeniesienie przez filozoficzny anarchizm zagadnienia współpracy obywateli z państwem z normatywnych relacji między autorytetem państwa, a więc jego uprawnieniem do posłuszeństwa oddanych i ich zobowiązaniem do takiego posłuszeństwa, do empirycznych relacji wynikających z ewaluacji jego dokonań prowadzi do sformułowania creda tego nurtu współczesnej myśli politycznej:

Uprawnienia i zobowiązania (bądź obowiązki) nie wyczerpują zagadnienia moralności. Może bowiem równie dobrze być tak, iż państwo nie dysponuje uprawnieniem do wydawania rozkazów niemniej jednak jego działania mogą być moralnie usprawiedliwione, a uprawnienia pogwałcone $\mathrm{w}$ czasie tych działań mogą okazać się nie bardziej ważne niż inne względy, na przykład potrzeba porządku. Może być też tak, iż państwo, które posiada takie uprawnienie, w pewnych okolicznościach nie będzie moralnie usprawiedliwione, gdy je zrealizuje. Nie ma nic

${ }^{7}$ Simmons w: C.H. Wellman and A.J. Simmons, Is There a Duty to Obey the Law?, Cambridge 2005, s. 193. 
paradoksalnego w takich konkluzjach kiedy tylko uwolnimy się od poglądu, że moralność jest tylko wąskim i sztywnym systemem nakazów i zakazów ${ }^{8}$.

Tam, gdzie uprawnienia i zobowiązania nie wyczerpują zagadnienia moralności lub, by rzecz ująć bardziej precyzyjnie, nie konstruują moralnej relacji państwa z obywatelami i obywateli z państwem, autorytet państwa i zobowiązanie polityczne obywateli nie istnieją. Państwo może liczyć na określone postępowanie obywateli, jeśli ci sami uznają je za moralnie słuszne, a oni z tego samego powodu mogą wesprzeć państwo. Posłuszeństwo i nieposłuszeństwo obywatelskie jakkolwiek są kategoriami, które znajdują poczesne miejsce w refleksji filozoficznego anarchizmu, to jednak nie pozostają w jakimkolwiek związku wzajemnego wynikania. Filozoficzny anarchizm dopuszcza jedno i drugie, żadnemu nie przypisuje ani koncepcyjnego, ani moralnego pierwszeństwa. Afirmuje kondycję obywateli, którzy sami nieustannie decydują kiedy mają być państwu posłuszni lub nieposłuszni, kiedy przestrzegać, a kiedy nie przestrzegać prawa. W najbardziej spektakularny, symboliczny sposób wyraża to anegdota, zgodnie z którą Emerson pyta Thoreau dlaczego ten jest więziony w zakładzie karnym hrabstwa Concord. Thoreau miał odpowiedzieć: „A dlaczego ty tu nie jesteś, Waldo?”9

Rekapitulując, istota filozoficznego anarchizmu sprowadza się do nierozłącznego połączenia dwóch założeń. Pierwsze z nich, w całości zaczerpnięte $\mathrm{z}$ anarchizmu politycznego, sprowadza się do wskazania na brak autorytetu jakiegokolwiek państwa i tym samym na brak jakiegokolwiek obowiązku posłuszeństwa po stronie jego obywateli. Drugie z nich, dla filozoficznego anarchizmu całkowicie autorskie i oryginalne, stanowi, że powyższe baraki nie kreują po stronie obywateli żadnego podstawowego obowiązku obalenia państwa. Wobec tych dwóch, wspólnych dla filozoficznych anarchistów założeń, różnice między nimi mają charakter zasadniczo drugorzędny i sprowadzają się tylko różnych filozoficznych uzasadnień braku autorytetu po stronie państwa.

II. Aprioryczny filozoficzny anarchizm. Ta postać filozoficznego anarchizmu ma dość jednoznaczną anarchistyczną genezę, która sięga ujęć Williama Godwina oraz Maxa Stirnera. Pierwszy z nich przyjmował, że każdy człowiek jest uprawniony do własnego indywidualnego sądu o rzeczach i posiadanie takiego sądu stanowi jedyną legitymowaną zasadę, która nakłada na niego obowiązek określonego postępowania ${ }^{10}$. Państwo, stanowiąc prawo,

${ }^{8}$ Simmons, Moral Principles and Political Obligation, s. 199.

${ }^{9}$ Ibidem, s. 200.

10 „Każdy człowiek jest zobowiązany do wykorzystania wszystkich swoich zdolności by odkryć to co słuszne i wprowadzić w czyn wszystko co uznał za słuszne (...). Tylko przekonanie człowieka, które opiera się na jego własnym rozumie stanowi jedyną legitymowaną zasadę, nakładającą na niego obowiązek określonego postępowania”. W. Godwin, Enquiry Concerning Political Justice, Oxford 1971, s. 96. 
wskazuje obywatelowi jak ma postępować i tym samym pozbawia go tego własnego sądu. Zmienia też jego motywację do działania, zastępując motywację własną, wewnętrzną, wynikającą z jego moralnego przekonania na zewnętrzną państwową sprowadzającą się do własnego interesu, który nakazuje uniknięcie kary ${ }^{11}$. Z kolei Stirner zakładał, że prawo człowieka wyraża się przez własną wolę. Państwo nie może powstrzymać się od sterowania wolą obywatela, gdyż nie dopuszcza ono możliwości jego kierowania się nią. Jest tak dlatego, że wolna wola obywatela, jego pragnienie do kierowania się nią, potrzeba samorealizacji staje w fundamentalnej opozycji do państwa, a państwo do niej ${ }^{12}$. Innymi słowy, obywatel jest ni mniej, ni więcej niewolnikiem państwa, gdyż wolność państwa (czy jak można to ująć inaczej suwerenność państwa, a więc samo jego istnienie) oznacza jego niewolę, a jego wolność stanowi o nieistnieniu państwa w jego władczej wobec obywatela postaci ${ }^{13}$.

Tym, czym była wolność dla Stirnera, tym dzisiaj dla apriorycznego filozoficznego anarchizmu jest autonomia. Jej koncepcyjny rodowód jest wyraźnie kantowski, mimo że sam Immanuel Kant nigdy nie zgodziłby się na posłużenie się nią dla obrony z gruntu anarchistycznego przesłania. Personifikacją współczesnego filozoficznego jest Robert Paul Wolff. To on jest autorem argumentacji, która w najbardziej spektakularny sposób przeciwstawia autonomię jednostki autorytetowi państwa.

Wolff przyjmuje, że skoro najbardziej fundamentalną przesłanką filozofii politycznej jest dzisiaj założenie, iż ludzie są odpowiedzialni za swoje postę-

${ }^{11}$ Komentując wprowadzenie przez państwo zakazu zabijania, Godwin wskazywał, iż „całkowicie zmienia to istotę postępowania” człowieka. „Przedtem postępowałem tak ze względu na wewnętrzną doskonałość [takiej postawy - przyp. mój Z. R.]”. Teraz zaś, ponieważ to państwo zakazało takiego zachowania, ,postępuję tak, gdyż koś arbitralnie dołączył do tego ogromny ciężar, jakim jest mój własny interes”. Tym samym to, co stanowiło „cnotę rozumianą jako cechę inteligentnej istoty", przybrało postać wyrachowanej kalkulacji nikczemnika. Ibidem, s. 91.

12 „Państwo niczego bardziej się nie boi niż Mojej wartości, i przy każdej sposobności udaremnia moją samorealizację. Ja jestem śmiertelnym wrogiem państwa, przed którym zawsze stoi wybór: Ono albo ja. Dlatego państwo nie tylko pilnuje, bym nic nie znaczył, lecz również nastaje na to, co Moje (...) Czuję jednak coraz wyraźniej, że - w przeciwieństwie do państwa pozostaje mi jeszcze wielka władza, władza nad Sobą samym, tzn. nad wszystkim co tylko Mi jest właściwe i istnieje wyłącznie wtedy, gdy jest moje własne”. M. Stirner, Jedyny i jego własnośćc, przeł. J. i A. Gajlewiczowie, Warszawa 1995, s. 305.

13 ,... co oznacza wolność darowana, narzucona? Każdy uzna przecież, iż nie jest to wolność w pełnym znaczeniu tego słowa, gdyż wszelka wolność to w istocie wyzwolenie samego siebie; to znaczy, że wolnym mogę być na tyle, na ile pozwoli Mi ma Swojość. (...) Natomiast jeśli dadzą Wam wolność to okażą się łotrami, którzy dają więcej niż mają; rozdają nie własny, lecz kradziony towar. Darują Wam waszą własną wolność, którą winniście wziąć Sobie sami, a dają Wam wyłącznie dlatego, byście sami po nią nie sięgali, rozliczając przy okazji złodziei i oszustów. W swej przebiegłości wiedzą doskonale, że dana (narzucona) wolność nie jest żadną wolnością, ponieważ tylko ta, po którą sięga się samemu (...) płynie pod pełnymi żaglami. Darowana wolność natychmiast zwija żagle, gdy tylko nadejdzie burza lub ucichnie wiatr - jej żaglom potrzeba łagodnego, miarowego podmuchu. (...) Człowiek obdarowany wolnością, nie jest niczym innym aniżeli wyzwoleńcem, libertinusem, psem, który wlecze za sobą resztki łańcucha; jest niewolnikiem w szacie wolności”. Ibidem, s. 195-196. 
powanie, to przyjmuje się, że są oni zdolni do dokonania wyboru jak powinni postępować. Sam wybór jednak nie wystarcza, by wybierającemu przypisać odpowiedzialność za jego dokonanie i zgodne z nim postępowanie. Konieczne są tu dwa elementy - wolna wola oraz rozum. Brak jednego z tych elementów wyklucza odpowiedzialność za swoje postępowanie. To dlatego zgadzamy się, iż tak chorzy umysłowo, jak i dzieci nie są odpowiedzialne za swoje postępowanie lub też ich odpowiedzialność jest ograniczona. Ci pierwsi nie posiadają wolnej woli, a ci drudzy rozwiniętej zdolności kierowania się rozumem. Każdy człowiek zatem, który posiada i wolną wolę, i rozum, jest zobowiązany do ponoszenia odpowiedzialności za swoje postępowanie. Zobowiązanie to nie jest zależne od faktycznego stopnia jego zaangażowania w proces refleksji, deliberacji czy innego rodzaju dociekań. Nawet całkowite ich zaniechanie nie zwalnia go z obowiązku odpowiedzialności za swoje postępowanie. Uznajemy, iż może on postępować moralnie słusznie lub niesłusznie, zawsze jednak ponosi odpowiedzialność za swoje postępowanie. Nie ulega wątpliwości, że człowiek uznaje własne ograniczenia moralne, ale aby być odpowiedzialny, sam dokonuje ich oceny niezależnie od opinii innych. Tych ostatnich może wysłuchać, ale moralne decyzje odejmuje samodzielnie. Jego decyzje moralne przybierają postać imperatywów. Możemy zatem przyjąć, iż stanowi on prawo dla samego siebie. To zaś czyni go autonomicznym podmiotem w rozumieniu kantowskim. Nie podlega on woli nikogo innego. Może postępować tak, jak inni mu nakażą, nigdy zaś dlatego że oni mu tak nakażą ${ }^{14}$.

Człowiek, będąc autonomicznym podmiotem, którego wolna wola i rozum czyni zdolnym do dokonywania moralnych wyborów, nie może zrezygnować z odpowiedzialności za swoje postępowanie. Może natomiast, i często tak robi, zrezygnować z części czy nawet całości swojej autonomii. Rezygnując z własnej refleksji, deliberacji czy dociekań albo też decydując się na podległość cudzym rozkazom, może zrezygnować ze swej autonomii w określonych sprawach, sytuacjach, przedziale czasowym bądź też na całe życie we wszystkich okolicznościach. Przykładowo, rezygnuję w istotnym zakresie z mojej autonomii, kiedy oddaję się w ręce lekarza, poddając się przepisanej przez niego terapii, gdyż moje własne przemyślenia w tej kwestii nie byłyby najprawdopodobniej bardziej przydatne niż jego. Podobnie, w zasadniczym stopniu rezygnuję z mojej autonomii, gdy podporządkowuję się woli kapitana samolotu, którym podróżuję, szczególnie wtedy, gdy naszym udziałem jest katastrofa lotnicza lub tylko jej uprawdopodobniona możliwość. W obydwu przypadkach, rezygnując z mojej autonomii czy to w wyniku zaniechania własnych przemyśleń medycznych, czy poddania się woli doświadczonego pilota, nie uznaję autorytetu żadnego z nich nad sobą samym ${ }^{15}$.

\footnotetext{
${ }^{14}$ Ibidem, s. 12-14.

15 Ibidem, s. 15-16.
} 
Przykłady te obrazują paradoks ludzkiej kondycji. Sprowadza się do tego, że człowiek, szczególnie człowiek współczesny, rozpoznaje swoją potrzebę autonomii, potrzebę bycia swoim panem, który sam sobie stanowi prawo, a jednocześnie zdaje sobie sprawę, jak często jest biernym przedmiotem tak technologi, jak i biurokracji, kompleksowości których nie może zrozumieć. Rozwiązanie tego paradoksu stanowi istotę przesłania apriorycznego filozoficznego anarchizmu i zasadniczy filar jego argumentacji. Niezależnie jak często człowiekowi przychodzi rezygnować z części lub całości jego autonomii, moralny wymiar jego kondycji, ludzkiej kondycji nie pozwala mu nigdy zrezygnować z oddania sprawie swojej autonomii, z zaangażowania po jej stronie, z samego zobowiązania do dążenia do bycia autonomicznym podmiotem. Jak to ujmuje Wolff:

Rezygnacja ze zobowiązania do moralnej autonomii nie wchodzi w grę. Ludzie nie będą w sytuacji lepszej niż dzieci, gdy zaakceptują władzę innych nie tylko z konieczności, ale też uczynią to dobrowolnie i zaniechają obowiązku nieustannego rozważania słuszności tego co czynią. Kiedy oddaję się w ręce innego, i pozwalam mu określić zasady, którymi się kierował w moim postępowaniu, to rezygnuje z wolności i rozumu, które dają mi godność. Jestem wtedy winien tego, co Kant mógł nazwać grzechem dobrowolnej heteronomii ${ }^{16}$.

Takie ujęcie nakazuje wręcz odrzucenie autorytetu państwa:

To, co definiuje państwo, to autorytet, a więc uprawnienie do rządzenia. Podstawowym zobowiązaniem człowieka jest autonomia. Wydaje się, iż nie może mieć miejsca rozwiązanie konfliktu między autonomią jednostki a domniemanym autorytetem państwa. Tak dalece jak człowiek wypełnia swoje zobowiązanie do tego by być autorem swoich decyzji będzie on opierał się żądaniu państwa do posiadania autorytetu wobec niego. Oznacza to, iż zaprzeczy on, że jest zobowiązany do posłuszeństwa prawom państwa tylko dlatego, że są one prawami. W tym sensie wydaje się, iż anarchizm jest jedyną doktryną zgodną z cnotą autonomii ${ }^{17}$.

Wszelkie inne doktryny polityczne, które poszukują pogodzenia autonomii jednostki z autorytetem państwa popadają w utopię, która wymyka się jakiejkolwiek logicznej weryfikacji. Twierdzenie bowiem, że istnieją (czy nawet mogą istnieć) sprawiedliwe państwa, które z sukcesem łączą autonomię jednostki z autorytetem państwa jest tak samo logicznie zasadne, jak zapewnianie o istnieniu „okrągłego kwadratu czy żonatego kawalera”. Gdy zatem nie ma, bo nie może być, państwa cieszącego się autorytetem, a więc prawem do rządzenia swoimi obywatelami, przed każdym bez wyjątku stoją tylko

\footnotetext{
${ }^{16}$ Ibidem, s. 71-72.

${ }^{17}$ Ibidem, s. 18.
} 
dwie drogi. Albo przyjmie on pozycję filozoficznego anarchizmu i potraktuje wszystkie państwa jako pozbawione wszelkiej legitymacji, których wszelkie nakazy należy samemu ocenić i osądzić przed przed ich spełnieniem, albo zrezygnuje $\mathrm{z}$ donkiszoterii dążenia do autonomii w sferze polityki i podda się w wyniku jakiejś domniemanej obietnicy państwa, które w danym momencie wyda mu się najbardziej sprawiedliwe czy wspaniałomyślne ${ }^{18}$. Wybór taki jest o tyle łatwy, że więzi jakiegokolwiek obywatela z jakimkolwiek państwem są logicznie takie same czy, lepiej rzecz ujmując, w ogóle ich nie ma. Wszystkie państwa są przecież pozbawione autorytetu, a wszyscy obywatele nie są zobowiązani do posłuszeństwa jakiemukolwiek państwu ${ }^{19}$.

III. Aposterioryczny filozoficzny anarchizm. Korektę apriorycznego filozoficznego anarchizmu stanowi aposterioryczny filozoficzny anarchizm. Kiedy ten pierwszy zakłada, iż państwo z samej swej natury nie może cieszyć się autorytetem, a więc posiadać legitymacji do rządzenia obywatelami, ten drugi przyjmuje, że choć wszystkie istniejące państwa rzeczywiście są pozbawione takiej legitymacji to jednak nie należy kategorycznie wykluczać, iż taką legitymację mogą kiedyś uzyskać. Jak argumentuje czołowy przedstawiciel i propagator aposteriorycznego filozoficznego anarchizmu A. John Simmons, w samej definicji państwa nie ma bowiem nic, co mogłoby wykluczać taką legitymację. To, że nie można wskazać żadnego państwa cieszącego się taką legitymacją wynika wyłącznie z niechlubnych zaszłości wszystkich tych instytucji i ich agend ${ }^{20}$. Innymi słowy, brak autorytetu państwa nie wynika z racjonalnej spekulacji, lecz z empirycznej obserwacji. Ta ostatnia takiej drogi do uzyskania przez konkretne państwo konkretnej legitymacji bynajmniej nie zamyka.

A zatem zasadniczy argument aposteriorycznego anarchizmu filozoficznego sprowadza się do wskazania z jednej strony jakie filozoficzne przesłanki

18 Ibidem.

${ }^{19} \mathrm{~W}$ charakterystycznym dla tej argumentacji fragmencie Wolff pisze: „W pewnym sensie możemy scharakteryzować anarchistę jako człowieka bez swojego kraju, ponieważ niezależnie od związków jakie łączą go z krajem jego dzieciństwa, znajduje się on w dokładnie takich samych moralnych relacjach z »jego« rządem jak z rządem każdego innego kraju, w którym mogłoby mu się przytrafić zatrzymać na jakiś czas. Kiedy spędzam wakacje w Wielkiej Brytanii przestrzegam jej praw tak z powodu rozważnie pojmowanego interesu własnego, jak i z powodu oczywistych względów moralnych sprowadzających się do wartości ładu i porządku, dobra ogółu, które wynika z systemu ochrony własności itd. Wracając do Stanów Zjednoczonych, mam poczucie powrotu do mojego kraju i jeśli w ogóle o tym myślę wyobrażam sobie siebie jako tego, którego związki z prawem amerykańskim są bardziej intymne. Zostały one ogłoszone przez mój rząd, tym samym posiadam specjalne zobowiązanie do przestrzegania ich. Ale anarchista powiada mi, że moje uczucia mają czysto sentymentalny charakter i nie mają żadnej obiektywnej podstawy moralnej. (...) Moje posłuszeństwo amerykańskim prawom, jeśli mam być podmiotem moralnie autonomicznym, musi opierać się na tych samych założeniach, które przyjmuję za granicą”. Ibidem, s. 18-19.

${ }^{20}$ Por. Simmons, Philosophical Anarchism, s. 21. 
legitymacji państwa nie zostały spełnione w praktyce politycznej, a z drugiej w jakich okolicznościach mogłyby one zostać w niej spełnione. Tak więc jeśli filozoficzne przesłanki legitymacji państwa mają charakter woluntarystyczny, egalitarystyczny czy komunitarystyczny, to należy wskazać, że istnieje możliwość zaistnienia takiego w pełni woluntarystycznego, egalitarystycznego czy komunitarystycznego państwa choć taka możliwość nie jest bynajmniej bliska prawdopodobieństwu ${ }^{21}$. Niezależnie więc od indywidualnych przekonań poszczególnych autorów, którzy mogą zostać zakwalifikowani jako aposterioryczni filozoficzni anarchiści, a więc ich większego optymizmu czy większego pesymizmu co do możliwości zaistnienia takich państw cieszących się określona legitymacją wszyscy oni dzielą jedno stanowisko metodologiczne. Sprowadza się ono do założenia o istnieniu pewnego ideału legitymizacji państwa, do którego państwa rzeczywiście istniejące mogą się zbliżać lub od którego mogą się oddalać. Co więcej, ideał taki stanowi dla aposteriorycznych anarchistów filozoficznych instrument ewaluacji istniejących państw, ich postępu lub regresu w procesie zbliżania się do tegoż ideału²2.

IV. Krytyka filozoficznego anarchizmu. Nie ulega wątpliwości, iż założenia filozoficznego anarchizmu muszą stanowić przedmiot łatwej i wdzięcznej wieloaspektowej krytyki. W literaturze przedmiotu prowadzona jest ona z co najmniej trzech perspektyw. Jak łatwo się domyśleć, wszystkie te per-

${ }^{21}$ Jak to ujmuje Simmons, ,W obrębie klasy aposteriori anarchizmów możemy wyróżnić teorie w najbardziej zasadniczy sposób odwołujące się do ideałów legitymacji, które głoszą oraz do optymizmu, który wyrażają co do możliwości zrealizowania tego ideału w realnym świecie polityki, a także do dystansu jaki dzieli ten ideał od rzeczywistego stanu rzeczy w jednej czy we wszystkich wspólnotach politycznych. Większość aposteriorycznych anarchistów nie jest oczywiście optymistycznie nastawiona ani co do rychłej realizacji ich ideałów (jeśli oni w ogóle bronią jakichkolwiek z nich), ani też te ich ideały nie są bardzo bliskie żadnej współczesnej wspólnocie politycznej”. Simmons, ibidem, s. 21.

${ }^{22}$ Istotnym problemem jest zatem jednoznaczne wskazanie, który autor może zostać zakwalifikowany jako aposterioryczny filozoficzny anarchista. Własna samoświadomość filozoficzna autora i autoidentyfikacja jako takiego anarchisty bez wątpienia przesądza zagadnienie tej przynależności, ale dotyczy to zaledwie radykalnie znikomej mniejszości autorów. Faktycznie natomiast założenie, iż wystarczy zarysować ideał państwa, którego dokładnego odpowiednika nie można znaleźć w świecie praktyki politycznej, ustrojowej czy prawnej kwalifikuje już autora takiego zarysu (tak akademickiego, jak i amatorskiego, tak politycznego, jak i apolitycznego) jako klasycznego aposteriorycznego anarchistę filozoficznego. Tak więc Simmons, który sam na mocy własnych deklaracji identyfikuje się jako taki właśnie anarchista uznaje, że przykładowo na identyczną kwalifikację, choć już bez takich osobistych deklaracji, zasługują we współczesnej angloamerykańskiej filozofii politycznej między innymi tacy jej prominentni przedstawiciele, jak M.B.E. Smith (Is There a Prima Facie Obligation to Obey the Law?, „Yale Law Journal” 82/1973); J. Raz (The Obligation to Obey the Law, w: The Authority of Law, Oxford 1973); L. Green (The Authority of the State, Oxford, 1988); D. Regan (,Law's Halo”, „Social Philosophy \& Policy”, Autumn 1986); A.D. Woozley (Law and Disobedience, London 1979); D. Lyons (Need, Necessity, and Political Obligation, „Virginia Law Review”, February 1979) oraz J. Feinberg (Civil Disobedience in the Modern World, „Humanities in Society” 2/1979). Patrz Simmons, Philosophical Anarchism, s. 35 przyp. 8 oraz s. 34 przyp. 2. 
spektywy przyjmują jeden wspólny, niepodważalny mianownik, który stanowi odniesienie do anarchizmu politycznego. Pierwsza perspektywa ma zatem charakter praktyczny, przede wszystkim personalny, druga zasadniczo cywilizacyjny, a trzecia najbardziej filozoficzny.

Punktem wyjścia dla krytyki z pierwszej z wymienionych tu perspektyw jest łączenie przez filozoficzny anarchizm radykalizmu założeń z konformizmem zaleceń. Rzeczywiście, łączenie bombastycznego założenia o braku jakiejkolwiek legitymacji po stronie jakiegokolwiek państwa ze wskazaniem na oczywiście intuicyjną zasadność niezliczonej ilości powodów by obywatele wszystkich tych państw okazywali im posłuszeństwo dokładnie tak jak państwa te od nich tego oczekują zarówno w stanowionym przez siebie prawie, jak i kreowanej przez siebie praktyce politycznej w pełni zasługuje na zakwestionowanie takiego stanowiska jako anarchistyczne. W rzeczy samej łatwo wskazać, iż konstruowanie anarchistycznych założeń, propagowanie i co najważniejsze, intelektualne lansowanie siebie samych jako personifikacje anarchistycznego etosu stanowi przejaw niespotykanej hipokryzji autorów filozoficznego anarchizmu ${ }^{23}$. Wystarczy bowiem porównać w tym kontekście postawy i wybory życiowe współczesnych politycznych i filozoficznych anarchistów - na przykład ludzi tego samego pokolenia Andreasa Baadera oraz Ulriki Meinhof z jednej strony i Roberta Paula Wolfa oraz Johna A. Simmonsa z drugiej. Ci pierwsi, klasyczni polityczni anarchiści odrzucając polityczną legitymację po stronie państwa i polityczne zobowiązanie po stronie jego obywateli podjęli zbrojną akcję zmierzającą do jego zniszczenia. Przypłacili to wyrokami pozbawienia wolności, których wykonanie skłoniło ich do podjęcia udanych prób samobójczych. Ci drudzy, filozoficzni anarchiści także odmawiając państwu politycznej legitymacji, a jego obywateli uwalniając od politycznego zobowiązania nie podjęli żadnych faktycznych działań świadczących o ich wyborze takiego właśnie stanowiska. Przeciwnie. Wybrali życie przykładnych, szanowanych obywateli, profesorów stanowych, a więc państwowych uniwersytetów amerykańskich, przechodząc wszystkie szczeble akademickiej kariery i ciesząc się wszelkimi także materialnymi przywilejami pracowników instytucji państwowych łącznie z hojnymi planami emerytalny$\mathrm{mi}^{24}$. Wypełniając wszystkie obowiązki wobec państwa nie popadali w konflikt ze stanowionym przezeń prawem. W amerykańskich realiach społecznych i gospodarczych dają więc bardzo wyrazisty przykład związania swoich losów z agendami państwa, w zamian za gwarancje prowadzenia życia przewidywalnego, dostatniego i pozbawionego ryzyka. Niezależnie zatem od ich groteskowej ideowej autoprezentacji jako szczerych anarchistów, trudno uznać, że ich

${ }^{23} \mathrm{Na}$ zarzut hipokryzji, który stawiają filozoficznemu anarchizmowi jego krytycy, wskazuje sam Simmons. Patrz Simmons, Philosophical Anarchism, s. 21.

${ }^{24}$ Wolff jest emerytowanym profesorem filozofii University of Massachusetts w Amherst. Simmons jest profesorem filozofii i prawa w University of Virginia. 
anarchizm zasługuje co najwyżej na miano „anarchizmu bezzębnego”, który narusza porządek polityczny i prawny państwa jeszcze w mniejszym stopniu niż ,przechodzenie przez ulicę na czerwonym świetle o trzeciej nad ranem" ${ }^{25}$.

Ta oczywista hipokryzja, która stanowi zasadniczą skazę na charakterze filozoficznych anarchistów jest też, zdaniem ich krytyków, osadzona na fundamentalnej intelektualnej nieuczciwości. Ta zaś sprowadza się do tego, że „odrzucenie politycznego zobowiązania wymaga zdystansowania się od od kompleksowej sieci zależności, przekonań i emocji związanych z członkostwem we wspólnocie politycznej” i poszukiwania filozoficznych argumentów, które bynajmniej zasadności takiego odrzucenia nie potwierdzają ${ }^{26}$. Filozofia polityczna, jak i filozofia prawa wypracowały już sporo argumentów wskazujących przecież, iż jest szereg okoliczności, które w konkretnych konstelacjach politycznych i pod rządami konkretnych regulacji prawnych zwalniają obywateli z politycznego zobowiązania, gdyż nie jest ono moralnie wymagane lub akceptowane. Nie oznacza to jednak by istniały filozoficzne podstawy do odrzucenia politycznego zobowiązania w każdej sytuacji i w całości, tak jak to próbują robić filozoficzni anarchiści ${ }^{27}$. Co więcej, ta fundamentalna intelektualna nieuczciwość filozoficznych anarchistów sprowadza się także do zamierzonej metodologicznej arbitralności, której najlepszym przykładem jest przeciwstawienie na zasadzie wzajemnego wykluczenia autonomii obywatela i autorytetu państwa przez Wolffa. Jego założenie, iż autonomia posiada status najwyższego moralnego zobowiązania dla każdego obywatela i tym samym zawsze wyklucza w jego sądach moralnych autorytet państwa jest tylko asercją Wolffa, która czyni cały jego wywód niewiarygodnym. Po pierwsze, bowiem, postępowanie obywatela (tak działanie, jak i zaniechanie) w sposób zalecany przez państwo, które odwołuje się do swojego autorytetu nie wyklucza jego odpowiedzialności za swoje postępowanie. Obywatel, który postępuje zgodnie z zaleceniem państwa, czyni tak, gdyż decyduje się tak postąpić właśnie na podstawie swojego sądu moralnego i swojego wyboru. Po drugie, Wolff wybrał autonomię w ujęciu Kanta, utożsamianą z atrybutem każdego racjonalnego człowieka, natomiast jego własne zapewnienia, iż należy dążyć do autonomii przypomina raczej ujęcie Johna Stuarta Milla, gdzie autonomia jest procesem określonego doskonalenia się człowieka, który zmierza do realizacji pewnego ideału. Jeśli tak jest, to ten ideał może konkurować z innymi ideałami w tym co postrzegamy jako dobre, pełne znaczenia życie. A to nie oznacza bynajmniej, iż w takiej walce konkurencyjnej ideał autonomii będzie zawsze zwycięzcą ${ }^{28}$.

${ }^{25}$ Gans, Philosophical Anarchism and Political Disobedience, s. 90.

${ }^{26}$ J. Horton, Political Obligation, Atlantic Highlands 1992, s. 160.

${ }^{27}$ Gans, Philosophical Anarchism and Political Disobedience, s. 90-91. Por. R.G. Wright, Legal and Political Obligation, Lanham, Md. 1992, s. 280.

${ }^{28}$ Horton, op. cit., s. 160. 
Druga z perspektyw, z której prowadzona jest krytyka filozoficznego anarchizmu, ma radykalnie odmienny charakter. Dla niej filozoficzny anarchizm nie jest nic nie znaczącą politycznie manierą grupki akademickich hipokrytów, którzy promują swój pseudo-radykalny etos, lecz faktycznym politycznym zagrożeniem, które może obrócić w gruzy zdobycze naszej zachodniej cywilizacji, zinstytucjonalizowane przez państwo liberalnej demokracji. W rzeczy samej, odmowa przez filozoficzny anarchizm wszystkim państwom politycznej legitymacji i pozbawienie wszystkich obywateli politycznego zobowiązania powoduje, iż nie istnieje moralna więź obywatela z państwem. Tym samym państwo, które nawet postępuje w sposób, z jakim obywatele się całkowicie moralnie utożsamiają nie jest uprawnione do stosowania wobec nich przymusu, gdyż nie dysponuje wobec nich żadnym autorytetem. Przymus taki, ze strony filozoficznego anarchizmu niczym nieusprawiedliwiony, kreuje po stronie obywatela wystarczający moralny powód, a faktycznie moralne prawo do stawienia oporu. Niezależnie jak bardzo taka konkluzja krytyków filozoficznego anarchizmu będzie odrzucana przez jego zwolenników, jak bardzo będą ci ostatni wskazywać na brak jakiegokolwiek absolutnego moralnego obowiązku by zawsze stawić opór państwu nie zmieni to faktu, iż zgodnie z ich argumentacją obywatel będzie zawsze do stawienia takiego oporu moralnie uprawniony. A taka konkluzja jest już konkluzją politycznego anarchizmu. Tym samym, powyższa argumentacja jest ze wszech miar zasadna, gdyż ,filozoficzny anarchizm faktycznie prowadzi nie tylko do twierdzenia, że nie mamy ogólnego zobowiązania do wspierania państwa, lecz także do konkluzji, iż powinniśmy wszyscy pracować dla obalenia państwa"29.

Tym samym filozoficzny anarchizm, niezależnie jak gorliwie zaprzeczają temu jego promotorzy i sympatycy, uchyla drzwi do moralnej legitymizacji politycznego anarchizmu. Rzecz jednak posiada jeszcze inny obok moralnego wymiar - wymiar psychologiczny. Jak to ujmuje jeden z zagorzałych krytyków filozoficznego anarchizmu:

Jeśli [właściwe temuż anarchizmowi - przyp. mój Z. R.] przekonanie zostanie szeroko zaakceptowane w liberalnych społeczeństwach, to doprowadzi do tragedii liberalnych reżimów. Polityczne zobowiązanie sprowadza się do szacunku dla legalnego autorytetu państwa oraz egzekwowania jego prawa i polityki. Jeśli jednak obywatele nie mają poczucia takiego zobowiązania wobec liberalnego państwa, to nie będą przejawiać żadnego szacunku dla jego prawnego autorytetu, będą mogli nawet czuć się urażeni wieloma $\mathrm{z}$ jego postanowień i będą mogli czuć, iż nie potrzebują przestrzegać prawa, którego nie akceptują. W takiej sytuacji państwo nie będzie miało innego wyboru niż trwanie dzięki użyciu siły. Bez wątpienia, wszystkie państwa, łącznie z państwami liberalnymi, stosują pew-

${ }^{29}$ Wellman w: C.H. Wellman and A.J. Simmons, Is There a Duty to Obey the Law? Cambridge 2005, s. 27-28. 
ną dozę przymusu by zapewnić uległość obywateli wobec postanowień swoich praw. Tam jednak gdzie obywatele nie mają poczucia zobowiązania wobec autorytetu państwa skala zastosowanego przymusu może być szeroka.

Co więcej, liberalne państwo, które rozlegle stosuje przymus by zapewnić uległość obywateli wobec postanowień swoich praw zaprzepaszcza swój własny charakter. Charakter ten jest definiowany jako zaangażowanie na rzecz zapewnienia podstawowych publicznych praw i wolności dla wszystkich. Jest to jedyny sposób zabezpieczenia kondycji, która pozwala tak na rozwój jednostek, jak i na szacunek dla nich. Podstawowe prawa i wolności takie jak wolność słowa, myśli, sumienia, zgromadzeń, własności prywatnej i właściwego stosowania prawa stanowią to co można nazwać „,politycznymi wolnościami”. Chronią one ludzi przed nadużyciami państwa, a tym samym zapewniają im niezależność niezbędną do krytykowania prawa i polityki państwa oraz do podejmowania wysiłków w celu ich zmiany zgodnie $\mathrm{z}$ ich własnymi koncepcjami tego co jest słuszne. Kiedy jednak jedynym powodem do posłuszeństwa obywateli będzie ekstremalne zastosowanie przymusu, charakter liberalnego państwa zmieni się radykalnie, a jego misja ochrony podstawowych praw i wolności zostanie zaprzepaszczona ${ }^{30}$.

A zatem, wbrew opiniom wielu swoich krytyków, filozoficzny anarchizm, swoim pseudo-radykalizmem nie zasługuje tylko na ironię i sarkazm, ale faktycznie stanowi filozoficzną propozycję o dramatycznie radykalnych, prawdziwie katastrofalnych skutkach politycznych ${ }^{31}$.

Z kolei trzecia z perspektyw pozwalających krytykować filozoficzny anarchizm nie koncentruje się ani na ułomnościach charakteru twórców i promotorów tego projektu, ani na jego politycznych konsekwencjach, lecz przede wszystkim na jego filozoficznym wymiarze. Argument, który pozwala ona zbudować jest następujący: Założenie filozoficznego anarchizmu, iż obywatele nie mają żadnego politycznego zobowiązania wobec państwa, a mimo to postępują zgodnie z jego zaleceniami pozwala zrównać ich relacje z państwem z relacjami jakie charakteryzują nieobywateli, a więc przede wszystkim pozostających na jego terytorium cudzoziemców ${ }^{32}$. Niezależnie jak bardzo takie założenie może wydawać się przekonywające, zasadniczo przeczy ono naszemu doświadczeniu, które jest fundamentem naszej świadomości. Wystarczy bowiem porównać zobowiązania wobec państwa tych dwóch kategorii osób w wypadku konfliktu zbrojnego, który może zagrozić samemu istnieniu te-

${ }^{30}$ S.M. DeLue, Political Obligation in a Liberal State, State University of New York Press, Albany 1988, s. 1-2.

${ }^{31}$ Por. T. Senor, What If There Are No Political Obligations?, A Replay to A.J. Simmons, „Philosophy \& Public Affairs”, 16 (Summer 1987), s. 260; T. Honore, Must We Obey? Necessity as a Ground of Obligation, „Virginia Law Review” (February 1981) 42-44; G. Klosko, Political Obligation and the Natural Duties of Justice, „Philosophy \& Public Affairs”, 16 (Summer 1994), s. 269-270.

${ }^{32}$ Patrz Simmons, Moral Principles and Political Obligations, s. 155-156. 
goż państwa. Jest rzeczą oczywistą, iż zajdzie zasadnicza różnica w odbiorze i ocenie ich postępowania jeśli tylko zdecydują się na opuszczenie terytorium zagrożonego państwa. Cudzoziemcy powrócą do siebie, obywatele natomiast zdezerterują, zamiast wypełnić obowiązek służby w siłach zbrojnych ${ }^{33}$. Trudno zaprzeczyć, iż istnienie takiej zasadniczej różnicy wynika z głębi naszych odczuć i intuicji moralnych ${ }^{34}$. A zatem, filozoficzni anarchiści, którzy budują bardzo istotną część swojej argumentacji na założeniu o sile sprawczej naszych uczuć i intuicji moralnych, które leżą u podstaw naszych sądów w konkretnych sytuacjach wskazujących na zasadność postępowania obywateli zgodnie z zaleceniami państwa, nie mogą zignorować tych oczywistych uczuć i intuicji, które wskazują na przekonanie o istnieniu politycznego zobowiązania. Nie można bowiem przekonująco argumentować, iż jedne przekonania społeczne są wiarygodne tylko dlatego, że służą dowodzeniu racji z którymi się utożsamiamy, a drugie niewiarygodne tylko dlatego, że nie służą takiemu dowodzeniu ${ }^{35}$.

Ta krytyka nie pozostaje bez odpowiedzi. Te zaś sprowadzają się do starych argumentów powszechnie obecnych w zachodniej myśli politycznej ${ }^{36}$. Pierwsza grupa zarzutów dotycząca hipokryzji i w rezultacie „bezzębnego anarchizmu" napotyka na argument wskazujący na moralną rozwagę i intelektualną uczciwość filozoficznego anarchizmu. Stoi on bowiem na straży niezawisłości sądów moralnych obywateli z jednej strony, a z drugiej ich roztropnej konstatacji, iż w największej ilości wypadków większe zło wyniknie z próby zbrojnego obalania państwa niż z jego moralnie nieakceptowanej polityki i prawa. Druga grupa zarzutów, która sprowadza się do przepowiedni, że odrzucenie politycznego zobowiązania prowadzi do uprawnienia albo obalenia państwa liberalnej demokracji, albo doprowadzenia do jego zwyrodnienia w nieliberalne państwo nadużywające przymusu natrafia na argument o zasadniczym wzmocnienia liberalnego państwa przez filozoficzny anarchizm. Jest tak dlatego, iż filozoficzny anarchizm występując przeciw polityce i prawu państwa, które wśród obywateli budzą najwięcej moralnych wątpliwości prowadzi do takiej przebudowy i praktyki politycznej, i systemu prawa, która czyni państwo bardziej akceptowanym przez obywateli, a wręcz takim, z którym będą mogli się utożsamiać. Będzie to państwo „bardziej otwarte, bardziej współpracujące, bardziej dobrowolne, stosujące mniej przymusu w obronie kontestowanych doktryn religijnych i moralnych, bardziej skrępowane w dysponowaniu tak pieniędzmi, jak i życiem swoich poddanych"37. Trzecia gru-

${ }^{33}$ Klosko, The Principle of Fairness and Political Obligation, s. 24.

${ }^{34}$ Patrz Simmons, Moral Principles and Political Obligations, s. 155-156.

${ }^{35}$ Klosko, The Principle of Fairness and Political Obligation, s. 25.

${ }^{36}$ Poniżej przytaczam najbardziej reprezentatywne argumenty obrony filozoficznego anarchizmu przez jego najbardziej wyrazistego autora i promotora jakim jest Simmons. Por. Simmons, Philosophical Anarchism, s. 27-34.

${ }^{37}$ Simmons, ibidem, s. 32. 
pa zarzutów, które podnoszą, iż polityczne zobowiązanie jest istotną częścią świadomości społecznej i podobnie jak należące do tej świadomości podstawowe przekonania moralne czy religijne nie może być ignorowane w filozoficznej analizie natrafia na następującą odpowiedź: Filozoficzny anarchizm opiera się właśnie na analizie, która dokonuje rozróżnienia między autentycznymi, głęboko osadzonymi sądami moralnymi, które (wbrew marksistom) nie są rezultatem indoktrynacji czy w konsekwencji fałszywej świadomości, za jaką stoją konkretne polityczne interesy tych, którzy czerpią wymierne korzyści z istnienia i funkcjonowania państwa a przekonaniami o wiążącym charakterze politycznego zobowiązania, które są ewidentnym dowodem siły sprawczej takiej właśnie indoktrynacji. Stąd też afirmuje autentyczne sądy moralne, a odrzuca wymuszone indoktrynacją przekonania.

V. Konkluzje. Zarówno ich krytyka jak i obrona przed krytyką wskazują, iż filozoficzni anarchiści posługują się aparatem pojęciowym liberalnej filozofii politycznej ${ }^{38}$. Nic nie wskazuje na to, by ze strony liberałów mogli liczyć na liczne konwersje. Zwolenników nie mają, ale są przez liberałów traktowani poważnie. To przeciw nim pisze się poważne akademickie rozprawy wydawane w najbardziej prestiżowych wydawnictwach akademickich ${ }^{39}$. Jest tak dlatego, że stanowią oni, zgodnie ze swoim zamierzeniem, problem filozoficzny a nie polityczny (w przeciwieństwie do tych libertarian, którzy są anarchokapitalistami, którzy postulują i nawet programują likwidację państwa, pośrednio inspirują do niepłacenia podatków itd.).To co ich faktycznie różni of liberałów, to tylko radykalizm ich naczelnych założeń - nie ma państw uprawnionych do posłuszeństwa swoich obywateli i nie ma obywateli zobowiązanych do posłuszeństwa swoim państwom. Te założenia, jakkolwiek zapewniły im koncepcyjną wyrazistość, zagwarantowały też ich ujęciom koncepcyjną stagnację. Ta ostatnia wynika z tego, iż założenia te wykluczają możliwość zaoferowania nam jakiegokolwiek wartościowego poznawczo opisu rzeczywistości. Czegóż bowiem możemy się od nich dowiedzieć o otaczającym nas świecie życia politycznego? Niczego. Twierdzenie, że wszystkie państwa pozbawione są wszelkiego autorytetu, jest równie bezużyteczne poznawczo jak swego czasu zapewnienia Herberta Marcusego, że wszystkie państwa są totalitarne czy C.B. McPhersona, że wszystkie są demokratyczne. W swojej metodologicznej arbitralności założenia te są tak kontrintuicyjne,

${ }^{38}$ Istotne znaczenie ma tu fakt, iż czołowi przedstawiciele filozoficznego anarchizmu biorą aktywny udział w akademickim liberalnym dyskursie politycznym. I tak, Wolff jest uznanym autorytetem w studiach nad myślą Kanta (Kant's Theory of Mental Activity 1962), a Simmons Locke'a (The Lockean Theory of Rights 1992).

${ }^{39}$ Wystarczy tu wskazać: J.H. Reiman, In Defense of Political Philosophy: A Reply to Robert Paul Wolff's in Defense of Anarchism, New York 1972 oraz Gans, Philosophical Anarchism and Political Disobedience. 
że nie skłaniają nikogo do podjęcia w oparciu o nie wysiłku konceptualizacji swojego politycznego doświadczenia.

Czy to jednak oznacza, że nie mają nic do zaoferowania współczesnej (a przede wszystkim przyszłej) filozofii politycznej? Sądzę, że mają i to dużo. W rzeczy samej posiadają potencjał właśnie do inspiracji liberalnej filozofii politycznej. Jest tak dlatego, że filozoficzny anarchizm zajmuje się zagadnieniami, które liberalizm pozostawia poza swoimi zainteresowaniami i koncepcyjnymi wysiłkami, mimo że metodologicznie byłby w stanie jej podjąć. Najkrócej rzecz ujmując filozoficzny anarchizm podejmuje trud konceptualizacji moralnej interakcji między pozbawionym uprawnienia do posłuszeństwa państwem a pozbawionym zobowiązania do posłuszeństwa obywatelem, podczas gdy liberalizm zajmuje się od Locke'a po Rawlsa dokładnie taką samą interakcją tyle, że między uprawnionym do posłuszeństwa państwem i zobowiązanym do niego obywatelem. Jeśli tylko zrezygnujemy z flagowego założenia filozoficznego anarchizmu, iż każde państwo pozbawione jest autorytetu i przyjmiemy, że istnieją tak państwa cieszące autorytetem, jak i te go pozbawione, to będziemy w stanie dokonać konceptualizacji podstaw do moralnej interakcji obywatela z państwem, która oddaje polityczne doświadczenia bogatsze niż naznaczone dobrodziejstwami liberalnej demokracji.

Liberalizm niegdyś dostrzegał potrzebę takiej konceptualizacji, ale nigdy nie zdołał jej rozwinąć. Gdy Locke argumentował za oparciem legitymacji państwa na zgodzie jego obywateli pisał jednocześnie o sytuacji, gdy takiej zgody nie można udzielić a państwu trzeba ulegać, bo skuteczne stawienie oporu nie jest możliwe. Pisał w bardzo znaczącym dla takiego ujęcia fragmencie Dwóch traktatów o rządzie:

Któż wątpi, iż greccy chrześcijanie wywodzący się od starożytnych posiadaczy ich kraju mogą sprawiedliwie zrzucić ciężar jarzma tureckiego, jaki już tak długo znoszą, gdy tylko będą władni to uczynić? A zatem, żaden rząd nie może zostać uprawniony do posłuszeństwa ze strony ludu, który nigdy dobrowolnie nie wyraził na to zgody. Nie można zakładać, że będzie to miało miejsce, jeśli nie znajdzie się on w stanie całkowitej wolności, by wybrać rząd i rządzących oraz nie będzie on miał co najmniej takich stałych praw, na które wyraził zgodę sam w nieskrępowany sposób bądź przez swoich reprezentantów ${ }^{40}$.

Tym samym Locke otwierał pole do klasycznej liberalnej analizy relacji między pozbawionym autorytetu państwem, a jego poddanymi czyli konstelacji, która dzisiaj stanowi kwintesencję punktu wyjścia filozoficznego anarchizmu. Zasadne jest zatem założenie, iż filozoficzny anarchizm pozwala na

\footnotetext{
${ }^{40}$ John Locke, Dwa traktaty o rządzie, przeł. Z. Rau, Warszawa 1992, s. 300-301.
} 
konceptualizację relacji między obywatelem a państwem, które wymykają się pojęciowemu aparatowi współczesnej liberalnej filozofii politycznej. W przypadku aksjologicznego sporu obywatela $\mathrm{z}$ państwem ta ostatnia dysponuje bowiem tylko dwiema kategoriami - oporu oraz obywatelskiego nieposłuszeństwa. Opór zakłada zastosowanie przemocy, gdy państwo posługuje się przymusem aby utrzymać instytucje, które służą planowanemu i trwałemu naruszaniu zasad uznawanych przez obywateli za słuszne i sprawiedliwe ${ }^{41}$. Obywatele stawiający opór ujawniają zatem głęboką opozycję do istniejącego systemu politycznego, który traktują jako daleki od sprawiedliwego ${ }^{42}$. Z kolei, obywatelskie nieposłuszeństwo ma zastosowanie wtedy, gdy obywatele akceptują doniosłość systemu politycznego, w tym konstytucyjnego i traktują go jako zasadniczo sprawiedliwy lecz incydentalnie sięgają, w wypadkach dyktowanych sumieniem, do środków ekstrakonstytucyjnych, w celu zmiany systemu prawa lub polityki państwa. Zastosowanie tych pozbawionych przemocy środków ostatecznie służy zapewnieniu stabilności tegoż systemu ${ }^{43}$. Obydwie te kategorie liberalnego dyskursu okazują się oczywiście nieprzydatne by wyrazić relacje analizowane przez filozoficzny anarchizm. Jest tak dlatego, że opór choć ze wszech miar uprawniony nie jest wskazany, natomiast obywatelskie nieposłuszeństwo jest faktycznie wykluczone przez nie incydentalny lecz fundamentalny charakter sporu obywatela $\mathrm{z}$ państwem. W rzeczy samej taki fundamentalny, a przede wszystkim permanentny spór aksjologiczny między obywatelem a państwem, który nie może być ostatecznie przezwyciężony ani przez stawienie oporu, ani przez zastosowanie obywatelskiego nieposłuszeństwa pozwala na moralną interakcję a nawet współpracę $\mathrm{z}$ obywatela $\mathrm{z}$ państwem. Ma to miejsce $\mathrm{w}$ sprawach uznanych przez obywatela za moralnie słuszne mimo, że współpracę tę nakazuje pozbawione moralnego umocowania państwo. Jest to właśnie konstelacja, którą zarysował Locke, a analizują dziś filozoficzni anarchiści bez wątpienia rozwijając klasyczną liberalną refleksję.

Niezależnie zatem od zasadności krytyki, z jaką często zasłużenie spotykają się wśród swych liberalnych adwersarzy, filozoficzni anarchiści w sposób istotny, a przede wszystkim wyważony zbliżają nas do zrozumienia złożoności moralnej kondycji tych wszystkich, którym tak jak niegdyś cierpiącym pod tureckim jarzmem locke'owskim greckim chrześcijanom przychodziło i przychodzi także dziś żyć pod władzą reżimów totalitarnych czy autorytarnych, a więc zasadniczo innych niż współczesna liberalna demokracja. To zaś bez wątpienia stanowi największy, najbardziej wyrafinowany, choć prawdo-

${ }^{41}$ Najlepszym przykładem takiego ujęcia jest doktryna Rawlsa. Patrz szczególnie J. Rawls, Teoria sprawiedliwości, przeł. M. Panafiuk, J. Pasek, A. Romaniuk, Warszawa 1994, s. 502, 538.

${ }^{42}$ Tamże, s. 504. Dobre wprowadzenie do zagadnienia oporu w doktrynie Rawlsa zawiera rozdz. VII w: P. Graham, Rawls, Oxford 2007.

${ }^{43}$ Por. Rawls, Teoria sprawiedliwości, s. 499-500, 511-515, 528. 
podobnie niezamierzony wkład filozoficznego anarchizmu do liberalnej filozofii politycznej. Z pewnością też zasługuje na kontynuację przez samych liberałów ${ }^{44}$.

${ }^{44}$ Problematykę tę podjąłem swego czasu między innymi w dwóch artykułach: Z. Rau, Some Thoughts on Civil Society in Eastern Europe and the Lockean Contractarian Approach, „Political Studies", XXXV, 1987, s. 253-69 oraz idem, The State of Enslavement: the East European Substitute for the State of Nature, „Political Studies”, XXXIX, 1991, s. 131-49. Całość tej problematyki zawiera Z. Rau, From Communism to Liberalism: Essays on the Individual and Civil Society, Łódź 1998. W polskiej literaturze przedmiotu syntezę tego zagadnienia zawiera Z. Rau, Liberalna dekonstrukcja systemu totalitarnego, ,Studia nad Faszyzmem i Zbrodniami Hitlerowskimi”, XXXIII, s. 311-328. 